\title{
ПРОЦЕСИ ЛІПОПЕРОКСИДАЦІЇ В СІМ’ЯНИКАХ ЗА УМОВ ПОСТРЕЗЕКЦІЙНОЇ АРТЕРІАЛЬНОЇ ЛЕГЕНЕВОЇ ГІПЕРТЕНЗІЇ
}

Вступ. Видалення великих об'ємів легень призводить до артеріальної легеневої гіпертензії, легеневого серця та його декомпенсації, венозного повнокров'я, застою і структурних змін в органах великого кола кровообігу, морфоогенез яких досліджено недостатньо.

Мета дослідження-вивчити особливості процесів ліпопероксидації в сім'яниках за умов пострезекційної артеріальної легеневої гіпертензії.

Методи дослідження. Морфометричними і біохімічними методами досліджено структури сім'яників 45-ти лабораторних статевозрілих білих щурів-самців. Через місяць від початку експерименту здійснювали евтаназію тварин шляхом кровопускання за умов тіопентал-натрієвого наркозу. В гомогенатах сім'яників визначали вміст дієнових кон'югатів, активних продуктів тіобарбітурової кислоти. Гістостереометрично на мікропрепаратах визначали кількість клітин епітеліосперматогенного шару, тубуло-інтерстиційний індекс, ядерно-цитоплазматичні відношення в ендотеліоцитах, сперматогенних епітеліоцитах, а також відносні об'єми пошкоджених ендотеліоцитів, сперматогенних епітеліоцитів. Проводили кореляційний аналіз між концентраціями дієнових кон'югатів, активних продуктів тіобарбітурової кислоти і досліджуваними гістостереометричними показниками з визначенням коефріцієнта (r) кореляції. Кількісні показники обробляли статистично.

Результати й обговорення. Правостороння пульмонектомія призводила до гіпертрофрії та розширення камер серця з домінуванням маси правого шлуночка і його дилатації, тобто легеневого серця. При легеневій гіпертензії та компенсованому легеневому серці рівень дієнових кон'югатів статистично достовірно $(p<0,001)$ зріс в 1,84 раза, при декомпенсації легеневого серця - в 3,16 раза порівняно 3 контрольним показником, а концентрація активних продуктів тіобарбітурової кислоти підвищилась, відповідно, у 2,1 та 7,3 раза. Змодельована патологія спричиняла зміни клітинного структурного гомеостазу, збільшення відносних об'ємів пошкоджених ендотеліоцитів та сперматогенних епітеліоцитів, зниження кількості клітин епітеліосперматогенного шару, тубуло-інтерстиційного індексу. Виявлено кореляційні зв'язки між вираженням процесів пероксидного окиснення ліпідів та структурними змінами в досліджуваному органі.

Висновки. Пострезекційна артеріальна легенева гіпертензія та легеневе серце призводять до суттєвого ремоделювання структур сім'яників, яке характеризується вираженим венозним повнокров'ям, гіпоксією, атрофрічними, дистрофрічними, некробіотичними, інорільтративними, склеротичними процесами, та вираженого посилення пероксидного окиснення ліпідів. Ступінь порушень ліпопероксидації при змодельованій патології корелює з вираженням змін структурного гомеостазу, відносними об'ємами пошкоджених ендотеліоцитів, сперматогенних епітеліоцитів, кількістю клітин епітеліосперматогенного шару, тубуло-інтерстиційним індексом у досліджуваному органі.

КЛЮчОВІ СЛОВА: сім'яники; ліпопероксидація; пострезекційна артеріальна легенева гіпертензія.

ВСТУП. Артеріальна гіпертензія в малому колі кровообігу (легенева гіпертензія) нерідко трапляється в клінічній практиці таускладнюється переважно гіперфункцією і гіпертрофрією правого шлуночка, тобто розвитком легеневого серця [1-3]. Дослідники вказують на те, що хронічне легеневе серце характеризується гіпертрофрією, дилатацією і дисорункцією м'яза правого шлуночка, що зумовлено ураженням легеневої паренхіми та/або легеневого судинного русла між місцем відходження стовбура легеневої (с) М. С. Гнатюк, С. О. Коноваленко, Л. В. Татарчук, 2020. артерії і місцем впадання легеневих вен у ліве передсердя. На сьогодні легеневе серце набуває все більшого значення у зв'язку зі значним зростанням частоти хронічних обструктивних захворювань легень, хронічних фрорм туберкульозу, професійних пошкоджень легень, при яких основною причиною втрати працездатності та летальності $€$ декомпенсація легеневого серця. Патогенез останньої складний і досить багатогранний, що значною мірою ускладнює адекватну своєчасну діагностику легеневої гіпертензії та легеневого серця. Варто вказати, 
що досі дискусійними залишаються питання про поширеність гіпертрофії правого шлуночка при хронічних обструктивних захворюваннях легень, а також про роль легеневої гіпертензії в патогенезі легеневого серця [2, 3], а структурні зміни інших органів, у тому числі сім'яників, при цій патології досліджено недостатньо $[4,5]$.

В останні роки морфологи все ширше використовують морфометричні методи дослідження, які дозволяють кількісно і найбільш об'єктивно оцінити різні фрізіологічні та патологічні процеси і логічно інтепретувати їх $[2,6]$.

Мета дослідження - вивчити особливості процесів ліпопероксидації в сім'яниках за умов пострезекційної артеріальної легеневої гіпертензії.

МЕТОДИ ДОСЛІДЖЕННЯ. Морфометричними і біохімічними методами досліджено структури сім'яників 45-ти лабораторних статевозрілих білих щурів-самців, яких поділили на 3 групи: до 1-ї входили 15 експериментальних інтактних тварин; до 2-ї - 22 щури 3 пострезекційною легеневою гіпертензією і компенсованим легеневим серцем; до 3-ї - 8 тварин 3 легеневою гіпертензією та декомпенсованим легеневим серцем. Через місяць від початку експерименту здійснювали евтаназію експериментальних тварин шляхом кровопускання за умов тіопенталнатрієвого наркозу. Окремо зважували камери серця та проводили їх планіметрію $[2,6]$.

У гомогенатах сім'яників визначали вміст дієнових кон'югатів (ДК) за здатністю до інтенсивного УФ-поглинання кон'югованих дієнових структур гідропероксидів ліпідів у діапазоні 232-234 нм і активних продуктів тіобарбітурової кислоти (ТБК-АП) за методом, що ґрунтується на здатності взаємодіяти в кислому середовищі 3 тіобарбітуровою кислотою $[7,8]$.

Із сім'яників білих щурів вирізали шматочки, які фріксували в $10 \%$ нейтральному розчині фрормаліну. Проводили їх через етилові спирти зростаючої концентрації і поміщали в парасрінові блоки. Мікротомні зрізи товщиною 5-7 мкм після депарафрінізації фрарбували гематоксилін-еозином, за Ван-Гізон, Маллорі, Вейгертом, толуїдиновим синім [6, 9].

Гістостереометрично на мікропрепаратах визначали кількість клітин епітеліосперматогенного шару (КЕСШ), тубуло-інтерстиційний індекс (TII) (відношення площі сім'яних канальців до інтерстиційної тканини), ядерно-цитоплазматичні відношення в ендотеліоцитах (ЯЦВЕН), сперматогенних епітеліоцитах (ЯЦВСе), а також відносні об'єми пошкоджених ендотеліоцитів (ВОПЕн), сперматогенних епітеліоцитів ВОПСе $[2,6,10]$.
Морфометрію досліджуваних структур сім'яників проводили за допомогою світлового мікроскопа Olimpus BX-23 із цифрровою відеокамерою і пакетом прикладних програм "Відео-тест 5,0" та "Відео-розмір 5,0".

Проводили кореляційний аналіз між концентраціями дієнових кон'югатів, активних продуктів тіобарбітурової кислоти тадосліджуваними гістостереометричними показниками з визначенням коеоріцієнта (r) кореляції. Кореляційні зв'язки оцінювали за чотирма ступенями: сильним $(r=0,7-0,9)$, значним ( $r=0,5-0,7)$, помірним $(r=0,3-0,5)$, слабким $(r<0,3)[6]$. Дослідження та евтаназію експериментальних тварин виконувализдотриманням Загальнихетичнихпринципів експериментів на тваринах, ухвалених на Першому національному конгресі з біоетики (Київ, 2001), відповідно до Європейської конвенції про захист хребетних тварин, що використовуються для дослідних та інших наукових цілей [11]. Отримані кількісні показники обробляли статистично. Обробку одержаних даних проведено у відділі системних статистичних досліджень Тернопільського національного медичного університету імені І. Я. Горбачевського МОЗ України у програмному пакеті Statsoft STATISTICA. Різницю між порівнюваними величинами визначали за критеріями Манна - Уїтні й Стьюдента [12].

РЕЗУЛЬТАТИЙ ОБГОВОРЕННЯ. ПЛаНіметрія та окреме зважування камер серця допомогли встановити, що правостороння пульмонектомія призводила до їх гіпертрофії та розширення 3 домінуванням маси правого шлуночка і його дилатації, тобто легеневого серця [2]. У змодельованих експериментальних умовах суттєво змінювалися процеси ліпопероксидації у тканинах сім'яників. Так, при легеневій гіпертензії та компенсованому легеневому серці рівень дієнових кон'югатів статистично достовірно $(\mathrm{p}<0,001)$ зріс із $(1,250 \pm 0,030)$ до $(2,300 \pm 0,050)$ ум. од./г, тобто в 1,84 раза, а при декомпенсації легеневого серця - у 3,16 раза порівняно 3 контрольним показником.

Майже аналогічно змінювалася при цьому концентрація активних продуктів тіобарбітурової кислоти у тканинах сім'яників. У контрольних спостереженнях вказаний біохімічний показник дорівнював $(0,640 \pm 0,012)$ мкмоль/кг, а при пострезекційній артеріальній легеневій гіпертензії $(1,360 \pm 0,030)$ мкмоль/кг. Між наведеними показниками виявлено виражену статистично достовірну різницю ( $<<0,001)$. При цьому остання цифрова величина перевищувала попередню у 2,1 раза.

При пострезекційній артеріальній легеневій гіпертензії та декомпенсованому легеневому 
серці описані зміни рівня активних продуктів тіобарбітурової кислоти в сім'яниках були більш вираженими. При цьому вказаний біохімічний показник з вираженою статистично достовірною різницею $(p<0,001)$ зріс із $(0,640 \pm 0,012)$ до $(4,700 \pm 0,120)$ мкмоль/кг, тобто в 7,3 раза (табл. 1).

Морфометрично виявлено, що кількість клітин епітеліосперматогенного шару за умов компенсованого легеневого серця статистично достовірно ( $<<0,001)$ зменшилася на 13,8 \% (табл. 2), при його декомпенсації - на 30,9 \% ( $<<0,001)$, а тубуло-інтерстиційний індекс знизився, відповідно, на 12,5 та 25,0 \% (р<0,001). Виражені зміни наведених моророметричних параметрів свідчили про значне порушення сперматогенного та інтерстиційного компонентів сім'яників [10]. Ядерно-цитоплазматичні відношення в ендотеліоцитах судин за умов компенсації легеневого серця змінились на 2,3\% $(p<0,05)$, при його декомпенсації - на 7,6 \% ( $<<0,01)$, а в сперматогенних епітеліоцитах - на $6,4 \%(p<0,01)$ та 16,6 \% (p<0,001) відповідно. Виявлені зміни цих відношень вказували на порушення структурного клітинного гомеостазу $[2,6]$. У змодельованих експериментальних умовах також істотно змінилися відносні об'єми пошкоджених ендотеліоцитів та сперматогенних епітеліоцитів. Так, відносний об'єм пошкоджених ендотеліоцитів за умов пострезекційної легеневої гіпертензії і компенсованого легеневого серця 3 вираженою статистично достовірною різницею ( $p<0,001)$ збільшився у 2,05 раза порівняно 3 контрольним параметром, при декомпенсації легеневого серця - в 11,66 раза ( $p<0,001)$, а сперматогенних епітеліоцитів - у 2,1 та 19,7 раза відповідно ( $p<0,001)$.

Світлооптично у тканинах сім'яників спостерігали виражені судинні розлади, набряк строми, осередки дистрофрічно, некробіотично змінених ендотеліоцитів, сперматогенних епітеліоцитів, стромальних структур, локальні клітинні інфрільтрати, склеротичні процеси, десквамацію та проліферацію ендотеліоцитів (остання свідчила про наявність гіпоксії), ендотеліоцити судин 3 явищами набряку, просяканням їх мембрани протеїнами плазми. У деяких судинах виявлено вогнища фрібриноїдного набухання та некрозу, що вказувало на їх виражене пошкодження. Пошкодження структур сім'яників підтверджували наведені вище гістостереометричні параметри (табл. 2).

Таблиця 1 - Вміст дієнових кон'югатів і активних продуктів тіобарбітурової кислоти

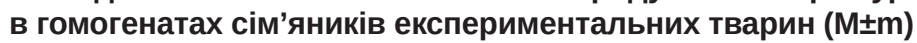

\begin{tabular}{|l|c|c|c|}
\hline \multirow{2}{*}{ Показник } & \multicolumn{3}{|c|}{ Група спостереження } \\
\cline { 2 - 4 } & 1 -ша & 2 -га & 3-тя \\
\hline ДК, ум. од./г & $1,250 \pm 0,030$ & $2,300 \pm 0,050^{\star \star \star}$ & $3,950 \pm 0,090^{\star \star \star}$ \\
\hline ТБК-АП, МКмоль/кг & $0,640 \pm 0,012$ & $1,360 \pm 0,030^{\star \star \star}$ & $4,700 \pm 0,120^{\star \star \star}$ \\
\hline
\end{tabular}

Примітка. *** - p<0,001 порівняно 3 1-ю групою.

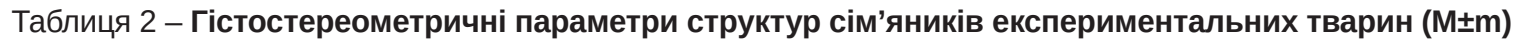

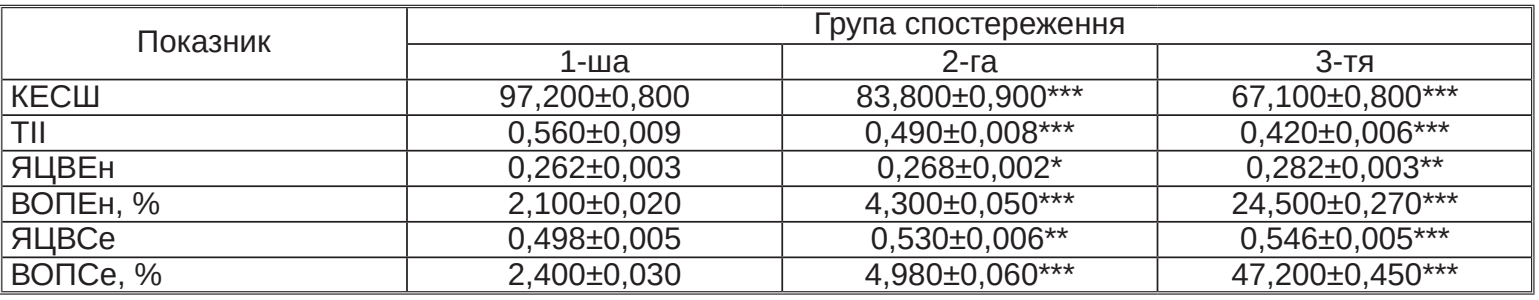

Примітка. * - $p<0,05 ;{ }^{* *}-p<0,01 ;{ }^{* \star *}-p<0,001$ порівняно 3 1-ю групою.

Під час кореляційного аналізу виявлено сильні позитивні взаємозв'язки між рівнями ДК, ТБК-АП та відносними об'ємами пошкоджених ендотеліоцитів і сперматогенних епітеліоцитів $(r=+0,84 \pm 0,03)$. Майже аналогічні кореляційні взаємозв'язки існували між вказаними показниками ліпопероксидації та ядерно-цитоплазматичними відношеннями в ендотеліоцитах і сперматогенних епітеліоцитах $(r=+78 \pm 0,03)$. Меншої сили негативні кореляційні взаємозв'язки виявлено між ДК, ТБК-АП та кількістю КЕСШ і ТІІ ( $r=-0,55 \pm 0,02)$. Отримані результати свідчать про те, що процеси пероксидного окиснення ліпідів відіграють важливу роль у розвитку патологічних змін у сім'яниках при змодельованій патології.

ВИСНОВКИ. Пострезекційна артеріальна легенева гіпертензія та легеневе серце призводять до суттєвого ремоделювання структур сім'яників, яке характеризується вираженим венозним повнокров'ям, гіпоксією, атрофічними, дистрофрічними, некробітичними, інфрільтративними, склеротичними процесами, та вираженого посилення пероксидного окиснення 
ліпідів. Ступінь порушень ліпопероксидації при змодельованій патології корелює з вираженням змін структурного гомеостазу, відносними об'ємами пошкоджених ендотеліоцитів, сперматогенних епітеліоцитів, кількістю клітин епітеліосперматогенного шару, тубуло-інтерстиційним індексом у досліджуваному органі.

\section{СПИСОК ЛІТЕРАТУРИ}

1. Galie N. Updated treatment algorithm of pulmonary arterial hypertension / N. Galie, P. Corris, A. Frost // J. Am. Coll. Cardiol. - 2013. - 62. - P. 60-72.

2. Гнатюк М. С. Морфометрична оцінка структурної перебудови судин гемомікроциркуляторного русла шлуночків легеневого серця / М. С. Гнатюк, О. Б. Слабий, Л. В. Татарчук // Наук. вісн. Ужгород. ун-ту. Серія "Медицина" - 2015. - Вип. 1 (51). - С. 10-12.

3. Семен Х. О. Особливості діагностики легеневої артеріальної гіпертензії / Х. О. Семен // Медицина транспорту України. - 2015. - № 2. - С. 72-80.

4. Грицуляк Б. В. Орхоепідидиміт / Б. В. Грицуляк, А. М. Спаська, В. Б. Грицуляк. - Івано-Франківськ : Прикарпатський нац. ун-т, 2010. - 188 с.

5. Morphometric analysis of peculiarities of the testicular arteries remodeling under the influence of rubomycin hydrochloride / S. O. Konovalenko, M. S. Hnatiuk, O. B. Yasinovskyi, L. V. Tatarchuk // Polish Science Journal. - 2019. - Issue 11. Warsaw, "iScience" Poland. P. 77-83.

6. Автандилов Г. Г. Основы количественной патологической анатомии / Г. Г. Автандилов. - М. : Медицина, 2002. - 240 с.

\section{REFERENCES}

1. Galie, N., \& Frost, A. (2013). Updated treatment algorithm of pulmonary arterial hypertension. J. Am. Coll. Cardiol., 62, 60-72.

2. Hnatiuk M.S., Tatarchuk, L.V., \& Slabyi, O.B. (2015). Morfometrychna otsinka strukturnoi perebudovy sudyn hemomikrotsyrkuliatornoho rusla shlunochkiv lehenevoho sertsia [Morphometric evaluation of the structural reconstruction of the vessels of the hemomicrocirculatory bed of the ventricles of the cor pulmonale]. Naukovyi visnyk Uzhhorodskoho universytetu, Seriia "Medytsyna" - Scientific Bulletin of the Uzhhorod University. Series "Medicine", 1 (51), 10-12 [in Ukrainian].

3. Semen, Kh.O. (2015). Osoblyvosti diahnostyky lehenevoi arterialnoi hipertenzii [Features of diagnostics of pulmonary arterial hypertension]. Medytsyna transportu Ukrainy - Medicine of Transport of Ukraine, 2, 72-80 [in Ukrainian].

4. Hrytsulyak, B.V., Spaska, A.M., \& Hrytsulyak, V.B. (2010). Orkhoepidydymit [Orhoepididymitis]. IvanoFrankivsk: Prykarpatskyi natsionalnyi universytet [in Ukranian].
Перспективи подальших досліджень. Усебічне дослідження структур сім'яників і процесів ліпопероксидації при артеріальній легеневій гіпертензії сприятиме суттєвому розширенню діагностики, корекції та профрілактики цієї патології.

7. КоробейниковаЭ. Н. Модификация определения продуктов ПОЛ в реакции с тиобарбитуровой кислотой / Э. Н. Коробейникова // Лаб. дело. - 1989. № 7. - С. 8-10.

8. Методы клинических лабораторных исследований / Под ред. В. С. Камышникова. -4-е изд. - М. : МЕДпресс-инорорм, 2011. - 750 с.

9. Горальський Л. П. Основи гістологічної техніки і морфоорункціональні методи досліджень у нормі та при патології / Л. П. Горальський. В. П. Хомич, О. І. Кононський. - Житомир : Полісся, 2011. - 288 с.

10. Базалицкая С. В. Диагностические методы и критерии оценки биопсийного материала при мужском бесплодии / С. В. Базалицкая, И. И. Горпиненко, А. М. Романенко // Здоровье мужчины. - 2004. № 3. - C. 216-221.

11. Резніков О. Г. Загальні етичні принципи експериментів на тваринах / О. Г. Резніков // Ендокринологія. - 2003. - 8, № 1. - С. 142-145.

12. Лапач С. Н. Статистические методы в медикобиологических исследованиях Excell / С. Н. Лапач, А. В. Губенко, П. Н. Бабич. - К. : Морион, 2001. -410 с.

5. Konovalenko, S.O., Hnatiuk, M.S., Yasinovskyi, O.B., \& Tatarchuk, L.V. (2019). Morphometric analysis of peculiarities of the testicular arteries remodeling under the influence of rubomycin hydrochloride. Polish Science Journal (11) Warsaw, "iScience" Poland, 77-83.

6. Avtandilov, G.G. (2002). Osnovy kolychiestviennoy patologicheskoy anatomii [Basics of quantitative pathological anatomy]. Moscow: Meditsyna [in Russian].

7. Korobeynikova, E.N. (1989). Modifikatsiya opredeleniya produktov $\mathrm{POL} v$ reaktsii s tiobarbiturovoy kislotoy [Modification of the determination of the products of LPO in reaction with thiobarbituric acid]. Lab.delo - Lab. Matter, 7, 8-10 [in Russian].

8. Kamyshnikov, V.S. (2011). Metody klinicheskikh laboratornykh issledovaniyakh [Methods of clinical laboratory research]. Moscow: MEDpress-inform [in Russian].

9. Horalskyi, L.P., Khomych, V.P., \& Kononskyi, O.I. (2011). Osnovy histolohichnoi tekhniky imorfofunktsionalni metody doslidzhen u normi ta pry patolohii [Fundamentals 
of histological technique and morphofunctional methods of research in normal and pathology]. Zhytomyr: Polissia [in Ukranian].

10. Bazalitskaya, S.V. (2004). Diagnostycheskye metody i kriterii otsenki biopsiynogo materiala pri muzhskom besplodii [Diagnostic methods and criteria for evaluation of biopsy material in male infertility]. Zdorovye muzhchiny - Men's Health, 3, 216-221 [in Ukrainian].
11. Reznikov, O.H. (2003). Zahalni etychni pryntsypy eksperymentiv na tvarynakh [General ethical principles of animal experiments]. Endokrynolohiia-Endocrinology, 8 (1), 142-145 [in Ukrainian].

12. Lapach, S.N., Gubenko, A.V., \& Babych, P.N. (2001). Statistichieskiye metody v miediko-biologicheskikh issliedovaniyakh Excell [Statistical methods in biomedical research Excell]. Kyiv: Morion [in Russian].

М. С. Гнатюк, С. О. Коноваленко, Л. В. Татарчук

ТЕРНОПОЛЬСКИЙ НАЦИОНАЛЬНЫЙ МЕДИЦИНСКИЙ УНИВЕРСИТЕТ ИМЕНИ И. Я. ГОРБАЧЕВСКОГО МОЗ УКРАИНЫ

\title{
ПРОЦЕССЫ ЛИПОПЕРОКСИДАЦИИ В СЕМЕННИКАХ В УСЛОВИЯХ ПОСТРЕЗЕКЦИОННОЙ АРТЕРИАЛЬНОЙ ЛЕГОЧНОЙ ГИПЕРТЕНЗИИ
}

\begin{abstract}
Резюме
Вступление. Удаление больших объемов легких приводит к артериальной легочной гипертензии, легочному сердцу и его декомпенсации, венозному полнокровию, застою и структурным изменениям в органах большого круга кровообращения, морфогенез которых исследован недостаточно.

Цель исследования - изучить особенности процессов липопероксидации в семенниках в условиях пострезекционной артериальной легочной гипертензии.

Методы исследования. Морфрометрическими и биохимическими методами исследованы структуры семенников 45-ти лабораторных половозрелых белых крыс-самцов. Через месяц после начала эксперимента осуществляли эвтаназию животных путем кровопускания в условиях тиопентал-натриевого наркоза. В гомогенатах семенников определяли содержание диеновых конъюгатов, активных продуктов тиобарбитуровой кислоты. Гистостереометрически на микропрепаратах определяли количество клеток эпителиосперматогенного слоя, тубуло-интерстициальный индекс, ядерно-цитоплазматические отношения в эндотелиоцитах, сперматогенных эпителиоцитах, а также относительные объемы поврежденных эндотелиоцитов, сперматогенных эпителиоцитов. Проводили корреляционный анализ между концентрациями диеновых конъюгатов, активных продуктов тиобарбитуровой кислоты и исследуемыми гистостереометрическими показателями с определением коэфрфициента (r) корреляции. Количественные показатели обрабатывали статистически.
\end{abstract}

Результаты и обсуждение. Правосторонняя пульмонэктомия приводила к гипертрофрии и расширению камер сердца с преобладанием массы правого желудочка и его дилатации, то есть легочному сердцу. При легочной гипертензии и компенсированном легочном сердце уровень диеновых конъюгатов статистически достоверно (p<0,001) вырос в 1,84 раза, при декомпенсации легочного сердца - в 3,16 раза по сравнению с контрольным показателем, а концентрация активных продуктов тиобарбитуровой кислоты повысилась, соответственно, в 2,1 и 7,3 раза. Смоделированная патология вызывала изменения клеточного структурного гомеостаза, увеличение относительныхобъемов поврежденныхэндотелиоцитов и сперматогенных эпителиоцитов, снижение количества клеток эпителиосперматогенного слоя, тубулоинтерстициального индекса. Выявлены корреляционные связи между выраженностью процессов перекисного окисления липидов и структурными изменениями в исследуемом органе.

Выводы. Пострезекционная артериальная легочная гипертензия и легочное сердце приводят к существенному ремоделированию структур семенников, которое характеризуется выраженным венозным полнокровием, гипоксией, атрофическими, дистрофическими, некробиотическими, инорильтративными, склеротическими процессами, и выраженному усилению перекисного окисления липидов. Степень нарушений липопероксидации при смоделированной патологии коррелирует с выраженностью изменений структурного гомеостаза, относительными объемами поврежденных эндотелиоцитов, сперматогенных эпителиоцитов, количеством клеток эпителиосперматогенного слоя, тубуло-интерстициальным индексом в исследуемом органе.

КЛЮЧЕВЫЕ СЛОВА: семенники; липопероксидация; пострезекционная артериальная легочная гипертензия. 


\section{LIPOPEROXIDATION PROCESSES IN THE TESTES IN CONDITIONS OF POSTRESECTION ARTERIAL PULMONARY HYPERTENSION}

\section{Summary}

Introduction. Removal of large volumes of lungs leads to arterial pulmonary hypertension, cor pulmonale and its decompensation, venous plethora, stagnation and structural changes in the organs of the large circulatory system, the morphogenesis of which has not been studied sufficiently.

The aim of the study - to learn the features of the processes of lipoperoxidation in the testes in the conditions at postresection arterial pulmonary hypertension.

Research Methods. Morphometric and biochemical methods investigated the structures of the testes of 45 laboratory adult white male rats. One month after the start of the experiment, euthanasia of the experimental animals was performed by bloodletting under conditions of thiopental anesthesia. The content of diene conjugates, the active products of thiobarbituric acid, was determined in the homogenates of the testes. Histostereometrically on micropreparations the number of cells of the epithelio-spermatogenic layer, tubulo-interstitial index, nuclear-cytoplasmic relations in endotheliocytes, spermatogenic epitheliocytes, the relative volumes of damaged endothelial cells, spermatogenic cells were determined. Correlation analysis was conducted between the concentrations of diene conjugates, the active products of thiobarbituric acid and the studied histostereometric parameters with the determination of the correlation coefficient (r). Quantitative values were processed statistically.

Results and Discussion. It was established that right pulmonectomy led to hypertrophy and enlargement of the chambers of the heart with the predominance of the mass of the right ventricle and its dilation, that is, the cor pulmonale. It was found that in the case of pulmonary hypertension and compensated cor pulmonale, the level of diene conjugates was statistically significant $(p<0.001)$ increased by 1.84 times, with decompensation of the cor pulmonale-3.16 times compared with the control indicator, and the concentrations of active products of thiobarbituric acid increased respectively 2.1 and 7.3 times. The simulated pathology led to changes in cellular structural homeostasis, the growth of relative volumes of damaged endothelial cells and spermatogenic epitheliocytes, decrease the number of cells in the epithelio-spermatogenic layer, the tubulo-interstitial index. Correlation relationships between the severity of lipid peroxidation processes and structural changes in the investigated organ are revealed.

Conclusions. Postresection arterial pulmonary hypertension and cor pulmonale lead to a significant remodeling of the structures of the testes, which is characterized by pronounced venous plethora, hypoxia, atrophic dystrophic, necrobitic, infiltrative, sclerotic psocesses and a pronounced increase in lipid peroxidation. The degree of disorders of lipoperoxylation in simulated pathology correlates with the severity of changes in structural homeostasis, relative volumes of damaged endothelial cells, spermatogenic epitheliocytes, the number of cells of the epithelio-spermatogenic layer, tubulo-interstitial index.

KEY WORDS: testes; lipoperoxidation; postresection arterial pulmonary hypertension.

Отримано 21.01.20

Адреса для листування: М. С. Гнатюк, Тернопільський національний медичний університет імені І. Я. Горбачевського МОз України, майдан Волі, 1, Тернопіль, 46001, Україна, e-mail: hnatjuk@tdmu.edu.uа. 